\title{
TERRESTRIAL ECOLOGICAL PROCESSES AND PROBLEMS ON SUB-ANTARCTIC ISLANDS
}

\author{
by Valdon R. Smith
}

(with three text-figures and one table)

\begin{abstract}
Smith, V.R. 2007 (23.xi): Terrrestrial ecological processes and problems on sub-Antarctic islands. Papers and Proceedings of the Royal Society of Tasmania 141(1): 99-110. https://tioi.org/10.26749/rstpp.141.1.99 ISSN 0080-4703. Department of Botany \& Zoology, Stellenbosch University, Private Bag X1, Matieland 7602, South Africa.
\end{abstract}

\begin{abstract}
On the basis of their vegetation and soils, sub-Antarctic island ecosystens are considered to be part of the tundra biome. However, subAntarctic island vegetation is more productive and nutrient cycling more rapid than in Northern Hemisphere tundra. Human occupation and exploitation on the islands has comprised mainly sealing, whaling and, in some instances, fishing and agriculture. Research stations have also been established for meteorological monitoring and scientific research. All these activities have affected the islands' floras and faunas but the greatest impact of humans has been through the introduction of alien organisms. Because the islands' indigenous biotas are species-poor and lack cardinal trophic groups that are common in other ecosystems (especially mammalian herbivores and predators), an introduced species that becomes invasive on an island can have insidious, but far-reaching, effects on ecosystem functioning. Such effects are the focus of this paper and the principal examples given are the effects of the introduced house mouse and a European slug on nutrient cycling at Marion Island. Manuring by seabirds and seals is also an important determinant of ecosystem structure and function at sub-Antarctic islands. Introduced domestic cats have reduced burrowing bird populations on some of the islands, and at Marion Island the populations of most surface-nesting birds have also declined, probably due to human exploitation of their oceanic food resources. This has far-reaching implications for ecosystem functioning. The sub-Antarctic region is also becoming warmer; at some islands this is coupled with decreased, and at others with increased, precipitation. Some implications of these climatic changes for ecological functioning are presented. The most important is that a warming climate will increase the probability of introduced organisms becoming established on an island. This, together with increasing human visitation and occupancy (the major cause of species introductions), implies that it is inevitable that the rate of establishment of invasive biota on the sub-Antarctic islands will increase.
\end{abstract}

Key Words: Sub-Antarctic islands, alien biota, climate change, ecosystem functioning, primary production, nutrient cycling, island ecology.

\section{INTRODUCTION}

Most oceanographers define the sub-Antarctic region as the zone between the Antarctic and Subtropical Convergences in the Southern Ocean. The latitudinal distribution of many marine organisms is limited by these boundaries, but this is less true of sub-Antarctic terrestrial organisms such as plants (Wace 1965), insects (Gressitt 1970), spiders (Pugh 2004) and avifauna (Barrat \& Mougin 1974). Hence, terrestrial biologists have tended to delimit the sub-Antarctic region on the basis of plant physiognomic, plant biogeographic, vegetation structure or climatic criteria. Lewis Smith (1984) used these criteria, especially those related to vegetation (Wace 1965) and climate (Holdgate 1964), to produce a regional classification of Antarctica and the Southern Ocean. This recognises six islands or island groups as belonging to the sub-Antarctic region (South Georgia, Macquarie Island, Marion and Prince Edwardislands, Îles Crozet, Îles Kerguelen, Heard and McDonald islands), all situated within a few degrees latitude north or south of the Antarctic Convergence. Because of the cold Bouvet Current from the Weddell Sea the Convergence extends farther north in the Indian Ocean so that relatively low-latitude islands such as Marion, Prince Edward and Îles Crozet are within this sub-Antarctic zone, even though they are farther north than the islands of the New Zealand continental shelf (Campbell, Antipodes, Auckland, Snares). These latter, because they possess a well-developed shrub and/or low tree vegetation, are considered to belong to the cool temperate zone, together with the Tristan da Cunha-Gough Island group, Île Amsterdam, Île Saint-Paul, Falkland Islands and southern Tierra del Fuego. At the other extreme, Bouvetøya, the South Sandwich Islands, South Orkney Islands and South Shetland Islands are considered to be in the maritime Antarctic zone.

This paper deals with ecological processes and problems on those islands considered as sub-Antarctic sensu Lewis Smith (1984). The ecological problems are mostly related to human activities, although the sub-Antarctic is also experiencing a more rapid rate of climate change than most other parts of the world, and this is also affecting the islands' ecosystems. Humans have long impacted on the biota and ecology of sub-Antarctic islands, in the eighteenth and nineteenth centuries through sealing and whaling and later through the establishment of meteorological and research stations. There also has been some agricultural activity, mainly on Îles Kerguelen. In most instances, the human footprint caused by these exploitative activities has been small but on some islands it has been more significant. For instance, between 1904 and 1965 South Georgia was the most industrialised and densely populated place (up to 2000 human inhabitants) south of the Antarctic Convergence, connected with sealing and whaling, and leading to large engineering works, massive local industrial pollution and acute and chronic oil spillages (Headland 1984). The two phases of human exploitation of the sub-Antarctic islands (whaling/sealing and research) and their effects are discussed by Frenot $e t$ al. (2005) and Convey et al. (2006), who also consider a third phase of human exploitation - the burgeoning Antarctic tourism industry. The details presented by those authors are not repeated here; rather, discussion concentrates on the effects that humans have had, and are likely to continue to have, on ecosystem functioning at sub-Antarctic islands through the intentional 
or inadvertent introduction of alien organisms and also by over-exploiting the surrounding marine ecosystem, which leads to declining seabird populations on the islands. How climatic change might interact with these human-mediated impacts on ecosystem functioning at the islands is also considered.

If an introduced organism becomes invasive on a remote island, its impact is likely to be much more difficult to mitigate or reverse than any effect caused by harvesting the natural populations, anthropogenic pollution or changing the type of land use at that island. To elucidate the effects of alien organisms on ecological fuctioning at sub-Antarctic islands it is necessary to consider to which of the world's ecosystem types the islands belong or most closely resemble, to highlight some important aspects of their terrestrial biotas and to examine what is known about ecological processes such as primary production, decomposition and nutrient cycling at the islands.

\section{The terrestrial sub-Antarctic biome}

A useful concept for categorising ecosystems is the "biome", a kind of "subcontinental biotic supercommunity" (Rutherford et al. 2006) or "large-scale ecosystem" (Cox \& Moore 2000). The concept recognises the role of macroclimate in shaping both the structural and functional properties of the ecosystem at the plant, animal and microbial levels but, because of the dominant nature of vegetation cover, biomes have been delimited mainly on vegetation criteria. On that basis, sub-Antarctic island vegetation has traditionally been considered to be tundra or, at least, tundra-like (Rosswall \& Heal 1975), since it shows strong physiognomic similarities to Northern Hemisphere tundra vegetation (low-growing, dominated by cryptogams, cushion plants, small shrubs, herbs and graminoids, mostly occurring on wet organic soils or peats), although few taxonomic affinities exist between the floras of the two regions. Two sub-Antarctic islands (Macquarie Island and South Georgia) were included in the International Biological Program's Tundra Biome Project (1967-74) and Macquarie Island is part of the International Tundra Experiment.

French \& Smith (1985) compared sub-Antarctic and maritime Antarctic terrestrial communities with Northern Hemisphere tundra (ranging from high Arctic polar deserts to temperate alpine tundra) using multivariate analyses of climatic, soil and vegetation parameters. This comparison showed that sub-Antarctic islands possess almost the full range of vegetation types found in Northern Hemisphere tundra (fig. 1), with the sub-Antarctic communities linked to their Northern Hemisphere counterparts at higher latitudes, due to the thermal influence of the Antarctic continent, climatic wetness and wind-chill. In effect, the vegetation of the sub-Antarctic islands resembles that of much higher latitudes (as much as 20 or even 30 degrees higher) in the Northern Hemisphere. More information on the structural and functional similarities and differences between subAntarctic island ecosystems and Northern Hemisphere tundra is provided by Smith \& Mucina (2006).

\section{Indigenous biota of sub-Antarctic islands}

All the sub-Antarctic islands are extremely remote (mostly $>2000 \mathrm{~km}$ from the nearest continent). Their indigenous terrestrial biotas (plants and non-marine-based animals)

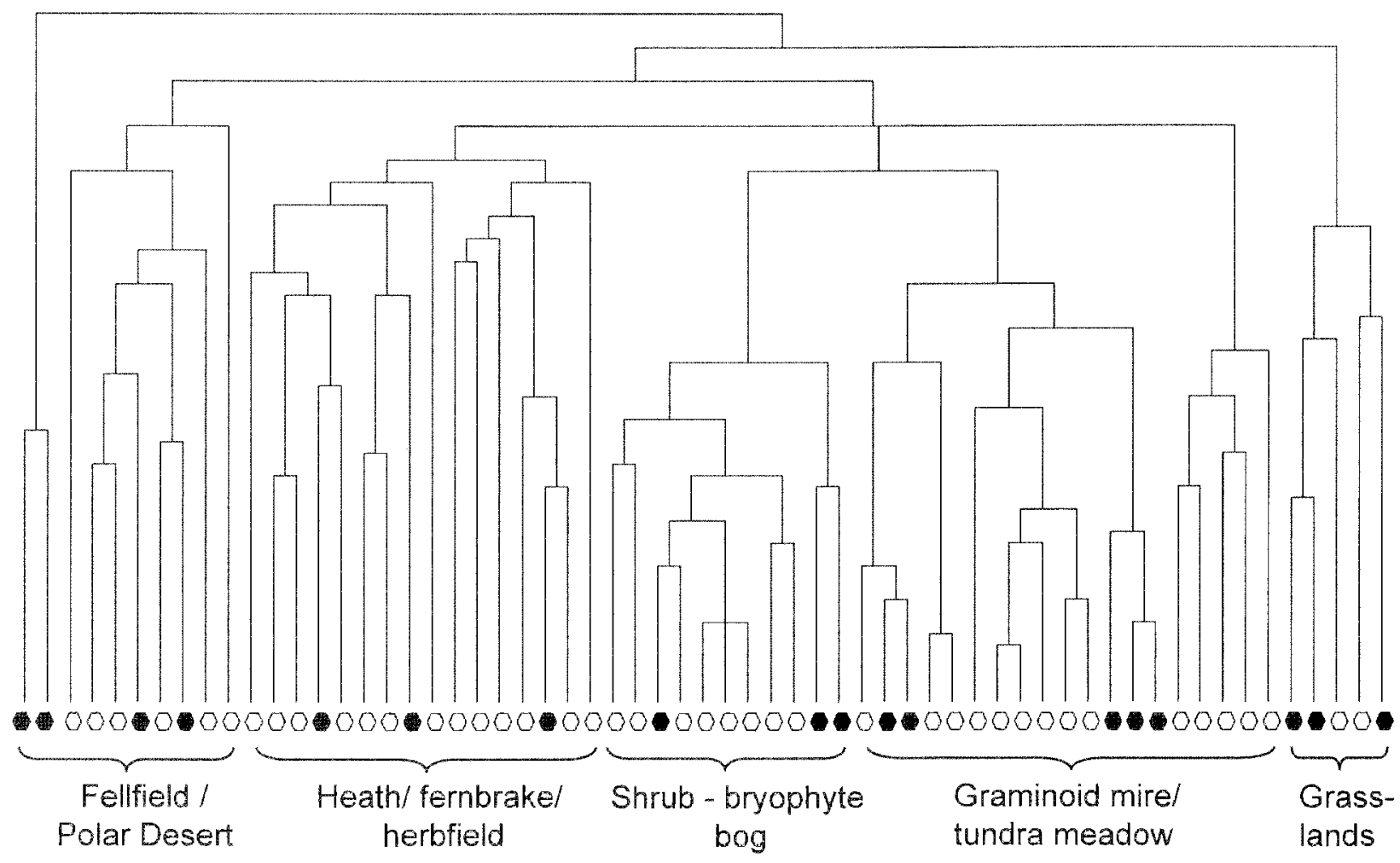

FIG. 1 - Euclidean-distance clustering of Northern Hemisphere tundra plant communities (open circles) and sub-Antarctic island plant communities (closed circles), based on their scores on the first four axes derived from a Principal Components Analysis of plant life-form, soil and climate parameters. Modified from French is Smith (1985). 
have been established by the slow process of immigration and colonisation over large expanses of ocean. Consequently this has resulted in a low species diversity. For instance, Lewis Smith (1984) listed 72 vascular plant species indigenous to the whole sub-Antarctic region, whereas the Canadian Arctic Archipelago, a climatically far more extreme region and about $25^{\circ}$ of latitude nearer the Pole than the sub-Antarctic, has more than 340 indigenous vascular plant species (Porsild 1964). About $10 \%$ of the 72 vascular species on sub-Antarctic islands are endemic to the sub-Antarctic region but only four species are endemic to a single island or island group. This low degree of endemism in the vascular floras of the sub-Antarctic islands reflects the short period of time that speciation could occur. Most of the islands are geologically young - only three (South Georgia, Îles Kerguelen and Heard Island) are substantially older than 10 million years and these were totally, or almost totally, glaciated during the Last Glacial Maximum period 12-27 kyr ago (Chown et al. 1998, Sachs \& Anderson 2005).

This paucity in species extends to other components of the islands' biotas. There are no indigenous land mammals or freshwater fish, and no island has more than three indigenous land bird species. The insect faunas are small; no island has more than 44 indigenous insect species. Of particular relevance to ecosystem functioning is that important trophic groups are absent, most notably vertebrate herbivores and predators. Even insect herbivores are poorly represented in the indigenous faunas; most insect species on the islands are detritivores. The low biodiversity of subAntarctic islands, together with the fact that their native species evolved in isolation, and mostly in the absence of competition or predation, has important implications regarding the susceptibility of ecosystem structure and function to human-introduced organisms.

\section{Alien biota of sub-Antarctic islands}

Human-introduced organisms form a significant component of the biota of sub-Antarctic islands. For instance, 108 alien vascular plant species have been recorded in the subAntarctic (Frenot et al. 2005), 50\% more than the number of indigenous species. Eight land mammal species have been introduced and become established on sub-Antarctic islands (Bonner 1984). Several salmonid fish species have been introduced to Îles Kerguelen and Îles Crozet (Davaine \& Beall 1997). Knowledge of alien terrestrial invertebrate taxa in the sub-Antarctic is incomplete, but $46 \%$ of the insect species (Chown et al. 1998) and 38\% of the springtail species (Gabriel et al. 2001) on Marion Island are introductions. Other introduced invertebrates on sub-Antarctic islands include enchytraeids, earthworms, mites, slugs, spiders, woodlice and a landhopper.

Invasive organisms represent a major threat to subAntarctic island biota and ecosystems and have been the topic of several reviews in the past decade. Chown et al. (1998) correlated biodiversity and invasive organism successes at Southern Ocean islands (sub-Antarctic and cool temperate zone islands) with abiotic parameters such as temperature, island age, size and altitude, distance to the nearest continent, extent of past glaciation and human occupancy. They showed that island area and temperature explained a high proportion of the variance in species richness in plants, insects and mammals - larger, warmer islands tend to have more species than smaller, colder ones. Human occupancy (numbers of humans on the island) was also important, but the relationship is confused by the fact that larger islands tend to have more humans. The same data as used by Chown et al. (1998) were re-analysed by Selmi \& Boulinear (2001), who introduced spatial autocorrelation into the analysis to show that dispersal ability and dispersal opportunity were important in determining island biodiversity. However, human occupancy was again shown to be crucial; human visitation enhances the opportunity for groups with a low dispersal ability (e.g., mammals, insects and plants) to reach the islands. Frenot et al. (2005) documented the origins and current status of alien plants, micro-organisms, invertebrates and vertebrates at the islands and discussed some implications of their presence to the islands' ecosystems. Convey et al. (2006) drew on that information to provide an overview of the current, and likely future, significance of biological invasions on sub-Antarctic islands. These reviews focus mostly on the effects the alien organisms have on structural aspects (species richness, population sizes of particular indigenous organisms or groups of organisms, vegetation structure and composition) of the islands' ecosystems. Here, the focus is on the effects of invasive organisms on ecosystem functioning.

\section{Ecological processes - primary production}

Despite its floristic poverty, sub-Antarctic island vegetation (at least the closed plant communities at low altitudes) exhibits a high annual primary production (ANP). Total (above- plus belowground) ANPs of the island communities are higher than at the 52 Arctic and sub-Arctic sites investigated as part of the International Biological Program's Tundra Biome Project and also mostly greater than at the more temperate oceanic moorlands and bogs that were also considered to be tundra in that study (fig. 2). Even compared with temperate plant communities, ANPs of the sub-Antarctic plant communities are high. In some instances they are higher than the maximum reported for temperate North American grasslands, and they are very much in the upper part of the range reported for temperate wetlands and marshes - vegetation types that are considered to be particularly productive.

Sub-Antarctic islands have a hyper-oceanic climate with precipitation throughout the year and small seasonal and diurnal variations in temperature. This leads to a long growing season. On Marion Island, for instance, the growing season for vascular plants (at low latitudes, below about 300 $\mathrm{m}$ ) is about 10 months (Huntley 1970) and bryophytes grow all year (Smith 1987a). Other sub-Antarctic islands have similarly long growing seasons (Wielgolaski et al. 1981). In contrast, Northern Hemisphere tundra communities have much shorter growing seasons, from a few weeks at high Arctic sites to about six months for sub-Arctic and alpine tundras. It is the long growing season, rather than any intrinsic capability of the plants to grow fast, that leads to the high annual primary production of sub-Antarctic vegetation. Productivity (defined here as the daily rate of aboveground production, since there are no data for belowground productivity at Northern Hemisphere tundra for comparison) is, in fact, quite low in the sub-Antarctic (e.g., between $0.9 \mathrm{~g} \mathrm{~m}^{-2}$ day $^{-1}$ and $3.1 \mathrm{~g} \mathrm{~m}^{-2}$ day $^{-1}$ for Marion Island vegetation; Smith 2007a). This is in part due to the cool summers experienced at sub-Antarctic islands. In contrast, sub-Arctic shrub- or dwarf shrub-dominated tundras have a growing season that, although short, is 


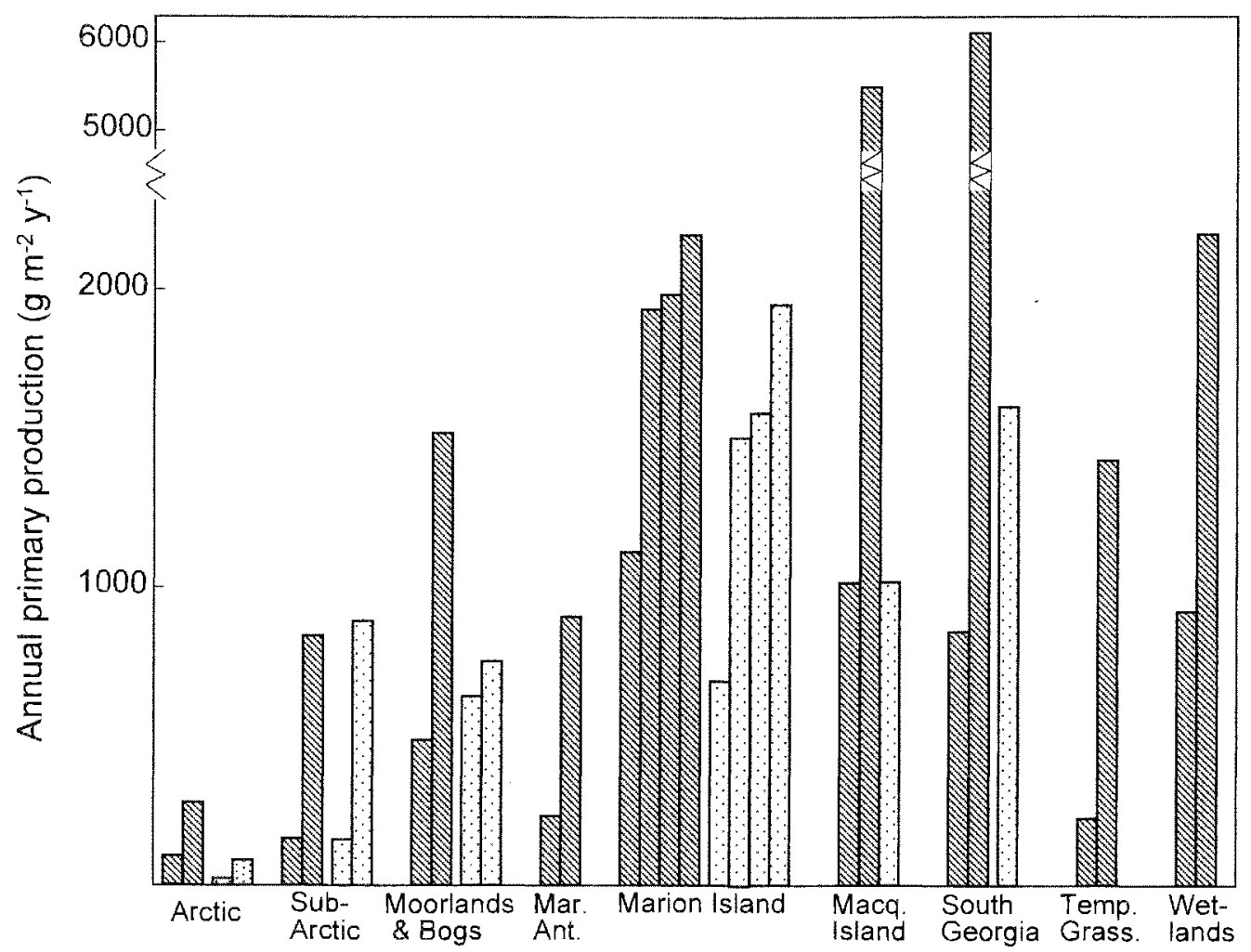

FIG. 2 - Total (above-plus belowground) annual primary production of sub-Antarctic island vegetation, Northern Hemisphere tundra, temperate oceanic moorlands and bogs, a maritime Antarctic island (Signy Island), temperate grasslands and temperate freshwater and tidal wetlands. Hatched bars are for graminoid-andlor bryophyte-dominated vegetation, stippled bars are for herb andlor dwarf shrub-dominated vegetation. For the sub-Antarctic islands each bar is for a single community. For the rest the left bar of the pair is the minimum, and the right bar the maximum, annual production reported for the particular vegetation type. Marion Island from Smith (1987a, b, 2007); Macquarie Island from Jenkin (1975); South Georgia from Clarke et al. (1971), Lewis Smith or Walton (1975) and Lewis Smith (1984); Arctic tundra from Pakarinen of Vitt (1973), Bliss (1975), Muc (1977), Webber (1978) and Miller et al. (1980); Sub-Arctic tundra from Wielgolaski \& Kjelvik (1973), Østby et al. (1975), Rosswall et al. (1975), and Wielgolaski et al. (1981); Oceanic moorlands and bogs from Doyle (1973) and Forrest do Smith (1975); Signy Island from Edwards (1973, 1974) and Collins et al. (1975); Temperate grasslands from Sims \& Singh (1978); Freshwater and tidal wetlands from Bernard of Gorham (1978), Reader (1978), and Whigham et al. (1978).

thermally more favourable for plant growth and show aboveground productivities of between 3 and $10 \mathrm{~g} \mathrm{~m}^{-2}$ day ${ }^{-1}$ (Wielgolaski et al. 1981). Sub-Antarctic vegetation productivity is more similar to that of sedge-moss and grassherb communities in the higher latitude Arctic $(2.2-3.3 \mathrm{~g}$ $\mathrm{m}^{-2}$ day ${ }^{-1}$; Wielgolaski et al. 1981). These communities also have cool summers.

Another reason for the low production rates of subAntarctic vegetation is low irradiance. High incidence of cloud cover results in daily radiation receipt at ground level being only about $50 \%$ of that at the top of the atmosphere. This is considerably lower than at the more continental polar and sub-polar regions of the Northern Hemisphere. On Marion Island, production efficiencies (energy fixation as a percentage of energy received in the incident photosynthetically active radiation during the growing season) of the plant communities range $0.7 \%-2.1 \%$ (Smith 2007a), almost identical to the range $(0.7 \%-2.4 \%)$ for sub-Arctic and Arctic tundras (Wielgolaski et al. 1981). This shows that, although the island vegetation grows more slowly during the growing season, it uses the incident radiation as effectively as do the Northern Hemisphere tundra vegetations. This is probably also true for other sub-Antarctic islands, although Jenkin \& Ashton (1970) reported low production efficiencies $(0.06 \%-0.46 \%)$ for Macquarie Island vegetation. However, those values were based on total radiation for the whole year, rather than photosynthetically active radiation received only in the growing season.

\section{Ecological processes - nutrient cycling}

Sub-Antarctic vegetation needs to take up substantial amounts of nutrients to support the high ANP. Marion Island plant communities require $7-27 \mathrm{~g} \mathrm{~N}, 0.5-3 \mathrm{~g} \mathrm{P}, 5-10 \mathrm{~g} \mathrm{~K}$ and 2-10 g Ca per square metre per year (Smith 2007a). For some nutrients (especially $\mathrm{N}$ and $\mathrm{P}$ ) the quantity taken up annually may be greater than their amounts contained in the vegetation and very much greater than the levels of plantavailable forms of those nutrients in the soil. This suggests fast cycling of nutrients through the plants and rapid rates of nutrient mineralisation in the soil, contrasting with Northern Hemisphere tundra, where nutrient uptake by the vegetation is smaller, soil nutrient mineralisation rates lower, and nutrient cycling through the vegetation slower, than on the sub-Antarctic islands (Dowding et al. 1981, van Cleve \& Alexander 1981). However, like tundra vegetation, it appears 
that sub-Antarctic vegetation utilises nutrients particularly efficiently in its primary production. For Marion Island communities, the nutrient cost of the ANP (the total amount of $\mathrm{N}, \mathrm{P}, \mathrm{K}, \mathrm{Ca}, \mathrm{Mg}, \mathrm{Na}, \mathrm{Si}, \mathrm{Fe}$ and $\mathrm{Mn}$ needed to produce $1 \mathrm{~g}$ of plant material, considering only the aboveground component) is between 17 and $40 \mathrm{mg}$ nutrients per $\mathrm{g}$ ANP. Nutrient costs for the ANP have not been reported for other islands, but for South Georgia and Macquarie Island estimates are possible by combining primary production information (Jenkin \& Ashton 1970, Clarke et al. 1971, Jenkin 1975, Lewis Smith \& Walton 1975, Lewis Smith 1984) with the plant nutrient concentration information (Jenkin 1972, Walton \& Lewis Smith 1980, Pratt \& Lewis Smith 1982, Lawson 1985) for the two islands. This gives approximate values of 29-44 mg nutrients per $\mathrm{g}$ ANP, similar to those for Marion Island vegetation. For all three islands, the nutrient costs of the ANP are very much in the lower part of the range (18-135 $\mathrm{mg} \mathrm{g}^{-1}$ ) reported for other vegetation types, ranging from tundra to tropical forest, by Swift et al. (1979).

An indication of the rapid nutrient cycling on Marion Island is given in table 1, which shows the pool sizes and flux rates of nitrogen in a graminoid-and bryophyte-dominated mire. This vegetation needs to take up $25 \mathrm{~g} \mathrm{~N}$ per square metre per year to support the annual production. Uptake rate during peak plant growth in midsummer is $336 \mathrm{mg}$ $\mathrm{N} \mathrm{m}^{-2}$ day $^{-1}$ which would deplete the plant-available $\mathrm{N}$ pool in about two days if that were not replenished. There is no direct nutrient input by seals or seabirds to the mire community, but most of the $\mathrm{N}$ in dry fallout and precipitation probably originates in rookeries and wallows on the nearby coast. However, the amount of $\mathrm{N}$ reaching the mire by dry fallout and precipitation, and also by biological $\mathrm{N}$ fixation, is negligible - only about $0.2 \%$ of the daily requirement of $336 \mathrm{mg} \mathrm{N} \mathrm{m}^{-2}$ day $^{-1}$.

There is a large reserve of organic $N$ in the mire peat and plant litter and mineralisation of the organic $\mathrm{N}$ is the obvious mechanism replenishing the plant-available $\mathrm{N}$ pool. Much effort has been devoted to estimating decomposition and nutrient mineralisation rates, using in vitro and in vivo soil incubation techniques and these yielded values which translated into very low estimates of $\mathrm{N}$ mineralisation rates in the field. For example, for the mire, a maximum rate of $48 \mathrm{mg} \mathrm{N} \mathrm{m}^{-2}$ day $^{-1}$ was found, which is only about $15 \%$ of the rate needed to meet the vegetation's daily requirement in midsummer. Smith \& Steenkamp (1992a) discussed these decomposition and mineralisation studies in more detail and emphasised their limitations, the most important of which was that they concentrated on $\mathrm{N}$ release by microbial organisms on their own and ignored the effect of the island's abundant soil fauna. The soil fauna comprises mainly detritivores and/or microbivores which are potentially able to enhance nutrient mineralisation rates by comminuting the decomposing substrate, by chemically altering it so that it is more amenable to microbial action and by enlarging the suite of micro-organisms acting on it. Using a microcosm approach it was subsequently shown that soil macro-invertebrates (moth and weevil larvae, earthworms, snails and slugs) do, in fact, greatly stimulate rates of nutrient release from peat and litter (Smith \& Steenkamp 1992b, 1993). Smith \& Steenkamp (1992c) incorporated the microcosm results into a model that considered macroinvertebrate densities, peat:macro-invertebrate mass ratios, micro-organism biomasses, $\mathrm{N}$ pool sizes of the soil microorganisms and of the macro-invertebrates, temporal changes in soil inorganic $\mathrm{N}$ concentration, and rates of $\mathrm{N}$ uptake by the vegetation. For the mire community considered in table 1, the model showed that macro-invertebrates cause the release of $345 \mathrm{mg} \mathrm{N} \mathrm{m}^{-2}$ day ${ }^{-1}$, sufficient to account for maximum rates of $\mathrm{N}$ uptake by the mire vegetation in midsummer (table 1). Hence, soil invertebrates are crucial to nutrient cycling on Marion Island and this is almost certainly true for all sub-Antarctic islands.

\section{Threats to ecological processes caused by invasive alien organisms}

If the rate of nutrient release from decomposing organic matter limits primary production at sub-Antarctic islands, and soil invertebrates are crucial facilitators of decomposition, any factor impacting on the soil invertebrate populations is likely to affect nutrient cycling and vegetation production at the islands. House mice (Mus musculus Linnaeus, 1758) have been introduced to most sub-Antarctic islands. On Marion Island their population (at least in summer and autumn) has recently increased, possibly in response to an ameliorating climate (Van Aarde \& Jackson 2007) and/or the eradication of the island's feral domestic cats in the early 1990s (Ferreira et al. 2006). The mice feed mainly on soil macro-invertebrates (Crafford 1990a, Smith etal. 2002) and they can annually remove up to six times the instantaneous biomass of a particular macro-invertebrate prey species. Since most of the prey species have long life-cycles the mice must impact severely on their populations, and the densities of

TABLE 1

Pools and fluxes of nitrogen in a mire community at Marion Island*

\begin{tabular}{ll}
\hline Pool / flux & Size / rate \\
\hline Annual amount taken up by vegetation & $25000 \mathrm{mg} \mathrm{N} \mathrm{m}^{-2} \mathrm{y}^{-1}$ \\
Uptake rate in midsummer & $336 \mathrm{mg} \mathrm{N} \mathrm{m}^{-2} \mathrm{day}^{-1}$ \\
Plant-available N pool & $700 \mathrm{mg} \mathrm{N} \mathrm{m}^{-2}$ \\
Precipitation and dry fallout input & $0.6 \mathrm{mg} \mathrm{N} \mathrm{m}^{-2} \mathrm{day}^{-1}$ \\
Biological N fixation & $0.2 \mathrm{mg} \mathrm{N} \mathrm{m}^{-2}$ day-1 $^{-1}$ \\
Organic N pool & $388000 \mathrm{mg} \mathrm{N} \mathrm{m}^{-2}$ \\
N mineralization by microorganisms alone & $48 \mathrm{mg} \mathrm{N} \mathrm{m}^{-2} \mathrm{day}^{-1}$ \\
Soil macroinvertebrate-stimulated N mineralisation & $345 \mathrm{mg} \mathrm{N} \mathrm{m}^{-2} \mathrm{day}^{-1}$ \\
\hline
\end{tabular}

* from Smith (1988) and Smith \& Steenkamp (1992c) 
the preferred prey (moth larvae, weevil larvae and adults, and spiders) have declined significantly at the island (Hänel 1999).

Predation by mice on terrestrial macro-invertebrates can be expected to result in decreased rates of nutrient mineralisation, which will decrease not only the quantity but also the quality (nutrient status) of plant material in the primary production. This will result in lower quality litter (Smith 2007a) that will decompose even more slowly. Changes in the balance between peat accumulation and decay will have implications for ecosystem structure since that balance determines the hydrological regime, which directs vegetation succession on the island (Gremmen \& Smith 2007).

Another consideration in the interaction between house mice, soil macro-invertebrate and nutrient cycling is that the European slug, Deroceras panormitanum (Lessona \& Pollonera, 1882), introduced to the island in the mid- to late 1960 s (Smith 1992) is now widely distributed and abundant in some habitats. Slugs are rarely preyed on by mice (Smith et al. 2002) but, like the indigenous macro-invertebrates, they markedly stimulate rates of nutrient mineralisation (Smith \& Steenkamp 1992b). Thus, slugs can potentially replace indigenous macro-invertebrates as nutrient recyclers in areas of high mouse density. However, Smith (2007b) showed that there are qualitative and quantitative differences in decomposition/mineralisation mediated by slugs and the indigenous soil macrofauna. For instance, the ratio of $\mathrm{C}$ to $\mathrm{N}$ mineralised by slugs from plant litter is 372:1 whereas for mineralisation by moth larvae (the most important mediators of nutrient release in most habitats on the island) it is 541:1 (difference significant at $\mathrm{P}=0.011$ ). In contrast, the C:P ratio released by slugs (4735:1) is not significantly different to that released by moth larvae $(4380: 1)$. These differences will lead to altered nutrient quality of the decomposing substrate, and ultimately to a shift in the balance between primary production and decomposition. The substitution, or partial substitution, of indigenous macro-invertebrates by slugs as facilitators of decomposition and nutrient cycling will be thus affect ecosystem structure and functioning on Marion Island.

Other introduced detritivores at the island are the chironomid midge Limnophyes minimus (Meigen, 1818) and a porcellionid isopod Porcellio scaber (Latreille, 1804). In some habitats midge larvae ingest greater amounts of litter than do the indigenous moth larvae (Hänel \& Chown 1998) and the large bodied isopod is also likely to ingest large quantities of litter (Slabber \& Chown 2002). Both will influence nutrient cycling, but studies like the one on the slugs are needed to establish their exact qualitative and quantitative effects. If an introduced species possesses a different habit to the one it might compete with or even replace, the influence on ecological processes might be substantial, even if the two are taxonomically similar. For instance, all sub-Antarctic islands have indigenous earthworms. Their habit, like all the introduced earthworms reported until recently, is epigeic (live in the organic surface layer of soil, and in the overlying litter layer, feed on organic debris only). In 2004 a new earthworm species, Allolobophora chlorotica (Savigny, 1826), was found at Îles Kerguelen, only near the glasshouses at Port-aux-Francais, suggesting that it was a recent introduction (Convey et al. 2006). The habit of A. chlorotica is a mix of endogeic (live in complex lateral burrows that extend through all layers of upper mineral soil, and eat mineral soil as well as organic matter) and anecic (build vertical burrows that extend from the soil surface well inro the mineral soil, feed on surface litter and cause vertical mixing of material in the soil profile). Convey et al. (2006) suggest that the habits of this species, especially the burying of organic matter in mineral soil, will have significant consequences for pedogenesis at the island, and it is quite likely that this will affect rates of nutrient cycling.

\section{Changes in nutrient inputs by seabirds}

Seabirds feed in the ocean and deposit substantial amounts of nutrients in the form of guano and moulted feathers on sub-Antarctic islands. A large proportion of the nutrients are added on the coast, at large penguin rookeries, and much of that washes back to the ocean without being incorporated into the soils or vegetation. However, there is substantial volatilisation of nitrogen as ammonia off the rookeries, some of which is deposited inland (Lindeboom 1984). In addition, birds that breed inland (mainly albatrosses, skuas, petrels and prions) have a significant effect on the productivity and nutrient status of the vegetation (Smith 1976a, 1978), and also on other aspects related to ecological functioning, such as the size and activity of soil micro-organism populations (Smith \& Steyn 1982, French \& Smith 1986, Grobler et al. 1987), rates of cellulose decomposition (Smith et al. 1993) and soil respiration (Smith 2003).

The populations of the surface-nesting species at Marion Island have declined since the mid-1970s (Crawford et al. 2003). Amongst the reasons suggested for this (Ryan \& Bester 2007) is a decreased food availability caused by overfishing in the Southern Ocean (and possibly increased competition for food by a rapidly increasing fur seal population), mortality associated with long-line fishing and, for the Southern Giant Petrel, possibly disturbance at breeding colonies. The decline in the seabird populations has resulted in a smaller nutrient input of avian products to the island. Between the 1974/75 and 2002 the inputs of N, P and Ca through guano and moulted feathers of surface-nesting birds declined by $4-11 \%$ in the shore zone and by $37-47 \%$ inland (fig. 3).

The data in figure 3 reflect the influence of only the surface nesters. In 2002 it is estimated that burrowing petrels and prions added about 185 tonnes $\mathrm{N}, 18$ tonnes $\mathrm{P}$ and 48 tonnes Ca to the Marion Island's ecosystem, much of that inland (Smith \& Froneman 2007). It is not known what the amounts added by burrowers was in the 1970 s since there are no population estimates for that period. However, it is known that domestic cats, which were introduced in 1949 and quickly became feral, had a deleterious effect on the populations of most, if not all, of the burrowing species. By 1975 the cat population was about 2000 and it was estimated that they killed about 450000 burrowing birds per year (Bester \& Skinner 1991). Tussock grassland comprising nitrophilous plant species is the climax vegetation of slopes occupied by burrowing birds and is supported by the nutrients by them (Smith 1976a). In 1971/72 tussock grassland occupied about $1 \%$ of the lowlands on the northeastern part of Marion Island (Smith 1976b, 1977). By 1991 this had decreased to $0.1 \%$, and by 2005 tussock grassland had completely disappeared from the area, being replaced mostly by low-nutrient status communities such as fernbrake. The decline is ascribed to the disappearance of burrowing bird colonies caused by cat predation (Gremmen \& Smith 2007), even though the cats were eradicated in 


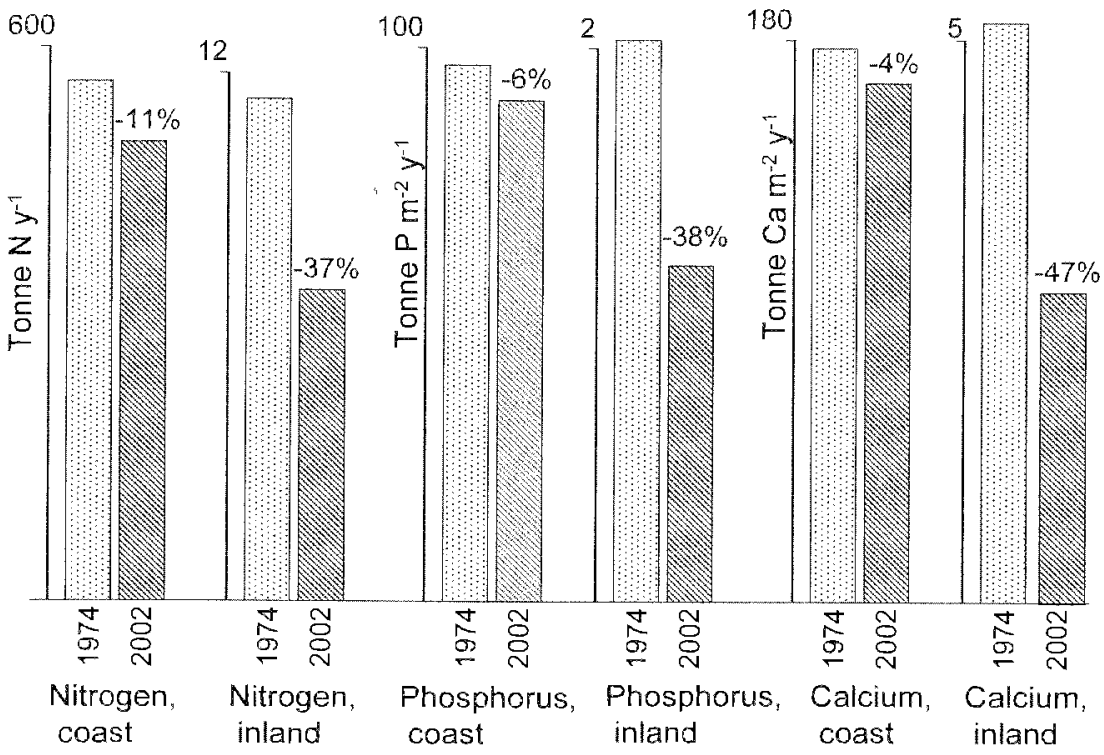

FIG. 3 - The amounts of nitrogen, phosphorus and calcium added annually as guano and moulted feathers of surface-nesting seabirds to the coastal and inland areas of Marion Island in 1974/75 and 2002/03. From Smith or Froneman (2007).

1991 (Bester et al. 2000). The petrel and prion populations do appear to be recovering (Cooper et al. 1995) but this has not yet led to the establishment of significant inland colonies. Tussock grasslands are widespread on nearby Prince Edward Island, where burrowing bird densities are also much higher and where cats were never present.

\section{Climate change and its effects on ecosystem function}

The sub-Antarctic climate has changed significantly over the past 40 years. Substantial warming has occurred at Macquarie Island (Adamson et al. 1988), South Georgia (Gordon \& Timmis 1992), Marion Island (Smith 2002), Îles Kerguelen (Frenot et al. 1997) and Heard Island (Budd 2000). In the same period total annual precipitation has decreased on Marion Island and Îles Kerguelen but has increased on Macquarie Island. Smith \& Steenkamp (1990) proposed some scenarios of the direct effects of warming (and drying) for the biota of Marion Island, but there have been few studies specifically focusing on the effects of climatic change on ecosystem processes in the sub-Antarctic. Most have concentrated on the ecophysiological responses of particular organisms (or groups of organisms) to abiotic factors such as moisture, light and temperature and it is only possible to speculate on the functional implications of climate change from their results.

Since primary production and decomposition rates are limited by low temperature and, in some plant communities, by soil moisture contents that are either sub-optimal or supraoptimal for soil microbial activity, climate change will directly influence ecological functioning at the islands. It is uncertain what effects warming will have on primary production. Photosynthetic optima of the sub-Antarctic and maritime Antarctic plants studied to date are above mean air temperatures at the islands on which they occur (Collins 1977, Bate \& Smith 1983, Pammenter et al. 1986, Edwards \& Lewis Smith 1988, Smith \& Gremmen 2001), so warming is expected to increase carbon assimilation rate.
All sub-Antarctic plants have the $\mathrm{C}_{3}$ photosynthesis pathway and might be expected to show increased rates of $\mathrm{CO}_{2}$ assimilation in response to the increasing atmospheric $\mathrm{CO}_{2}$ concentration being experienced in the sub-Antarctic ( $\mathrm{Smith}$ 1991, Yoshikawa-Inoue \& Ishii 2005). Hence, sub-Antarctic vegetation should become more productive under the current regime of warming and $\mathrm{CO}_{2}$ enrichment. However, so far the only studies of the influence of climatic change on primary production have been limited to individual species and do not give an unequivocal picture. For example, Smith \& Gremmen (2001) showed that changes in temperature and radiation at Marion Island by the amounts known to have occurred there in the past 35 years (temperature increased by $2^{\circ} \mathrm{C}$, total irradiation by $10 \%$ ) have a negligible effect on the annual amount of carbon acquired by the lichen Turgidosculum complicatulum ((Nyl.) J. Kholm. \& E. Kholm.) (= Mastodia tesselata, Hook. f. \& Harv., 1845), provided the thalli remain hydrated. Even more drastic changes - temperature up by $4^{\circ} \mathrm{C}$ and radiation up by $20 \%$ - will have a negligible effect on annual carbon acquisition by the lichen, again provided the thalli stay hydrated. Incorporating hydration/ desiccation cycles into the model resulted in a lowering of annual net $C$ uptake compared with current levels, but the reduction varied greatly depending on whether atmospheric drying or thallus drying was considered. However, these findings might not be pertinent for carbon acquisition by the vegetation, in which vascular and bryphyte species are much more important than lichens.

Soil respiration rate on Marion Island increases with increasing temperature and with soil moisture content up to field water-holding capacity (Smith 2003, 2005). It is likely that waterlogging depresses respiration rate. This has not been tested, but soil decomposition potential (measured as the loss in tensile strength of buried cotton strips) is lower at waterlogged (and at very dry) sites than at mesic sites (Smith et al. 1993); the same has been shown for other sub-Antarctic islands (Walton 1985, Lawson 1988) and also on maritime Antarctic Signy Island (Davis 1986, WynnWilliams 1988). The rate of decomposition mediated by microbes alone should thus increase with warming, and will 
either increase or decrease with wetting/drying depending on the current soil moisture regime at the particular plant community. Warming also increases the rate at which the island's insects and earthworms process plant litter and peat (Crafford 1990b, Smith \& Steenkamp 1990), leading to greater rates of nutrient release. However, ecophysiological studies on the island's weevil species (important agents of nutrient mineralisation in many of the habitats) show that upper lethal temperature for a particular species corresponds closely to the maximum microclimate temperature in the habitats occupied by that species (Van der Merwe et al. 1997), suggesting that climatic warming might be deleterious to the weevils' survival. Similarly, flightless moth larvae are probably the most important facilitators of nutrient release on the island and Klok \& Chown (1997) showed that continued warming will have a profound negative effect on the moth population, especially if the warming is accompanied by increasing aridity. Hence, climate warming could affect the island's insect populations directly, as well as indirectly by allowing a larger population of house mice at the island. Both effects are detrimental to the insect populations and will lead to decreased rates of nutrient recycling and lower primary production.

Other scenarios of the effects of climate change on ecosystem function can be proposed. For instance, if changing oceanic and atmospheric circulation patterns underlie the climate change being experienced at subAntarctic islands, as suggested by Adamson et al. (1988) and Rouault et al. (2005), then this could affect the the trophic dynamics of the seal and seabird populations by moving their feeding grounds, or making it harder/easier for them to reach the feeding grounds. This might be one reason for the decline in seabird populations at Marion Island. As mentioned above, the input of nutrients in avian products is an important determinant of all aspects of ecosystem functioning at Marion Island, and this is true for all sub-Antarctic islands.

Probably the most important effect of a warming climate is that it increases the ease with which invasive alien organisms can become established on sub-Antarctic islands (Bergstrom \& Chown 1999). Coupled with increasing human visitation and occupancy of the islands, the major source of introduced organisms (Chown et al. 1998, 2005, Whinam et al. 2005), it is likely that the rate of establishment of invasive biota on sub-Antarctic islands will increase. This is already happening. On Marion Island the number of new introductions has increased in the past decade, despite stringent measures having been put into place to prevent this (Slabber \& Chown 2002). At South Georgia there has been an explosion of several long-established, but previously alien plant populations due to the production of viable seed (which was not achieved until a few decades ago), several species that were recorded as rare transient aliens have suddenly reappeared at their former sites (presumably from a buried seed bank), and new species have also recently appeared (information on South Georgia kindly provided by Ron Lewis Smith). The pace of recent human-mediated introductions of spiders to islands in the Southern Ocean is at least 30 times more rapid than introductions resulting from natural dispersal (Pugh 2004). Like the examples of the introduced house mice and slugs at Marion Island, new introductions that succeed in becoming invasive are likely to have insidious, but profound, effects on ecosystem functioning on the sub-Antarctic islands.

\section{ACKNOWLEDGEMENTS}

I am grateful to Antarctic Tasmania for the invitation to present this paper at the International Forum on the subAntarctic and to Antarctic Tasmania and Stellenbosch University for financial support enabling me to attend the forum.

\section{REFERENCES}

Adamson, D.A., Whetton, P. \& Selkirk, P.M. 1988: An analysis of air temperature records for Macquarie Island: Decadal warming, ENSO cooling and Southern Hemisphere circulation patterns. Papers and Proceedings of the Royal Society of Tasmania 122: 107-112.

Barrat, A. \& Mougin, J.L. 1974: Données numériques sur la zoogéographie de l'avifauna antarctique et subantarctique. Comité National Français des Recherches Antarctiques 33: $1-18$.

Bate, G.C. \& Smith, V.R. 1983: Photosynthesis and respiration in the sub-Antarctic tussock grass Poa cookii. New Phytologist 95: 533-543.

Bergstrom, D.M. \& Chown, S.L. 1999: Life at the front: history, ecology and change on southern ocean islands. TREE 14: $472-477$.

Bernard, J.M \& Gorham, E. 1978: Life history aspects of primary production in sedge wetlands. In Good, R.E., Whigham, D.F. \& Simpson, R. (eds): Freshwater Wetlands. Ecological Processes and Management Potential. Academic Press, New York: 39-51.

Bester, M.N., Bloomer, J.P., Bartlett, P.A., Muller, D.D., Van Rooyen, M. \& Buchner H. 2000: Final eradication of feral cats from sub-Antarctic Marion Island, southern Indian Ocean. South African Journal of Wildlife Research 30: $53-57$.

Bester, M.N. \& Skinner, J.D. 1991: The Marion Island cat programme. South African Joumal of Antarctic Research 21: 117 .

Bliss, L.C. 1975: Devon Island, Canada. In Rosswall, T. \& Heal, O.W. (eds): Structure and Function of Tundra Ecosystems. Ecological Bulletins (Stockholm) 20: 17-60.

Bonner, W.N. 1984: Introduced mammals. In Laws, R.M. (ed.): Antarctic Ecology. Vol. I. Academic Press, London: 237-278.

Budd, G.M. 2000: Changes in Heard Island glaciers, King Penguins and Fur Seals since 1947. Papers and Proceedings of the Royal Society of Tasmania 133: 47-60.

Chown, S.L., Hull, B. \& Gaston K.J. 2005: Human impacts, energy availability and invasion across Southern Ocean Islands. Global Ecology and Biogeography 14: 521-528.

Chown, S.L., Gremmen, N.J.M. \& Gaston, K.J. 1998 : Ecological biogeography of Southern Ocean islands: Species-area relationships, human impacts and conservation. American Naturalist 152: 562-575.

Clarke, G.C.S., Greene, S.W. \& Green, D.M. 1971: Productivity of bryophytes in polar regions. Annals of Botany 35: 99-108.

Collins, N.J. 1977: The growth of mosses in two contrasting communities in the Maritime Antarctic: measurement and prediction of net annual production. In Llano, G.A. (ed.): Adaptations Within Antarctic Ecosystems. Smithsonian Institution, Washington: 921-933.

Collins, N.J, Baker, J.H. \& Tillbrook, P.J. 1975: Signy Island, Maritime Antarctic. In Rosswall, T. \& Heal, O.W. (eds): Structure and Function of Tundra Ecosystems. Ecological Bulletins (Stockholm) 20: 177-183.

Convey, P., Frenot, Y., Gremmen, N.J.M. \& Bergstrom, D.M. 2006: Biological invasions. In Bergstrom, D.M., Convey, P. \& Huiskes, A.H.L. (eds): Trends in Antarctic Terrestrial 
and Limnetic Ecosystems - Antarctica as a Global Indicator. Springer: 193-220.

Cooper, J., Marais, A.V.N., Bloomer, J.P. \& Bester, M.N. 1995: A success story: breeding of burrowing petrels (Procellariidae) before and after the extinction of feral cats Felis catus at sub-Antarctic Marion Island. Marine Ornithology 23: 33-37.

Cox, C.B. \& Moore, P.D. 2000: Biogeography: an Ecological and Evolutionary Approach, Gth edition. Blackwell, Oxford: $312 \mathrm{pp}$.

Crafford, J.E. 1990a: The role of feral house mice in ecosystem functioning on Marion Island. In Kerry, K. R. \& Hempel, G. (eds): Antarctic Ecosystems: Ecological Change and Conservation. Springer, Berlin: 359-364.

Crafford, J.E. 1990b: Patterns of energy flow in populations of the dominant insect consumers on Marion Island. Unpublished $\mathrm{PhD}$ thesis, University of Pretoria.

Crawford, R.J.M., Cooper, J., Dyer, B.M., Greyling, M.D., Klages, N.T.W., Ryan, P.G., Petersen, S.L., Underhill, L.G., Upfold, L., Wilkinson, W., de Villiers, M.S., du Plessis, S., du Toit, M., Leshoro, T.M., Makhado, A.B., Mason, M., Merkle, D., Tshingana, D., Ward, V.L. \& Whittington, P.A. 2003: Populations of surface nesting seabirds at Marion Island, 1994/95-2002/03. African Journal of Marine Science 25: 427-440.

Davaine, P. \& Beall, E. 1997: Introduction de salmonides en milieu vierge (Iles Kerguelen, Subantarctique): enjeux, resultats, perspectives. Bulletin Francais de la Pêche et de la Pisciculture 344/345: 93-110.

Davis, R.C. 1986: Environmental factors influencing decomposition rates in two Antarctic moss communities. Polar Biology 5: 93-103.

Dowding, P., Chapin, F.S. III., Wielgolaski, F.E. \& Kilfeather, P. 1981: Nutrients in tundra ecosystems. In Bliss, L.C., Heal, O.W. \& Moore, J.J. (eds): Tundra Ecosystems: A Comparative Analysis. Cambridge University Press, Cambridge: 647-683.

Doyle, G.J. 1973: Primary production estimates of native blanket bog and moadow vegetation growing on redamed peat at Gknamoy, Treland. In Bliss, L.C., Wielgolaski, FE. (cds): Frimary Production and Production Processes, Thutra Biome. Tundra Biome Steering Commirte, Stockholm: $141-15]$

Edwards, J.A. 1973. Vascular plant production in the maritime Antarcic. In Bliss, L.C., Wielgolaski, F.E. (eds): Primary Production and Production Frocesses, Tundra Biome. Tundra Biome Steering Commiztee, Stockholn: 169-175

Edwards, J.A. 1974: Studies on Colobonthus quitonsis (Kunth) Barth and Deschampsio antartica Desv. Unpublished PhD thesis. University of Birminghm.

Edwards, J.A. \& Lewis Smith, R.I. 1988: Photosynthesis and respiration of Colobanthus quitensis and Deschampsia antarctica from the Maritime Antarctic. British Antarctic Survey Bulletin 81: 43-63.

Ferreira, S.M., Van Aarde, R.J \& Wassenaar, T.D. 2006: Demographic responses of house mice to density and temperature on sub-Antarctic Marion Island. Polar Biology 30: $83-94$

Forrest, G.1. \& Smith R.A.H. 1975: The productivity of a range of blanket bog vegetation ypes in the northen Pennines. Journat of Eology 63: 173-202.

French, D.D. \& Smith, V.R. 1985: A comparison between Northern and Southern Hemisphere tundras and related ecosystems. Polar Biology 5: 5-21.

French, D.D. \& Smith, V.R. 1986: Bacterial populations in soils of a sub-Antarctic Island. Polar Biology 6: 75-82.

Frenot, Y., Chown, S.L., Whinam, J., Selkirk, P.M., Convey, P., Skotnicki, M. \& Bergstrom, D.M. 2005: Biological invasions in the Antarctic: extent, impacts and implications. Biological Reviews 80: 45-72.

Frenot, Y., Gloaguen, J.J., \& Tréhen, P. 1997: Climate change in
Kerguelen Islands and colonization of recently deglaciated areas by Poa kerguelensis and $P$. annua. In Battaglia, B., Valencia, J., \& Walton, D.W.H. (eds): Antarctic Communities: Species, Structure and Survival. Cambridge University Press, Cambridge: 358-366.

Gabriel A.G.A., Chown S.L., Barendse J., Marshall D.J., Mercer R.D., Pugh P.J.A. \& Smith V.R. 2001 : Biological invasions of Southern Ocean islands: the Collembola of Marion Island as a test of generalities. Ecography 24: 421-430.

Gordon, J.E. \& Timmis, R.J. 1992: Glacier fluctuations on South Georgia during the 1970s and 1980s. Antarctic Science 4: 215-226.

Gremmen, N.J.M. \& Smith, V.R. 2007: Terrestrial vegetation and dynamics. In Chown, S.L. \& Froneman, P.W. (eds): The Prince Edward Islands: Land-Sea Interactions in a Changing Ecosystem. African Sun Media, Stellenbosch (in press).

Gressitt, J.L. 1970: Subantarctic entomology and biogeography. Pacific Insects Monograph 23: 295-374.

Grobler, D.C., Toerien D.F. \& Smith, V.R. 1987: Bacterial activity in soils of a sub-Antarctic Island. Soil Biology e' Biochemistry 19: 485-490.

Hänel, C. 1999: The distribution and abundance of macroinvertebrates in the major vegetation communities of Marion Island and the impact of alien species. Unpublished M.Sc. Thesis, Uniyersity of Pretoria.

Hänel, C. \& Chown, S.L. 1998: The impact of a small, alien invertebrate on a sub-Antarctic terrestrial ecosystem: Limnophyes minimus (Diptera, Chironomidae) at Marion Island. Polar Biology 20: 99-106.

Headland, R. 1984: The Island of South Georgia. Cambridge University Press, Cambridge: 293 pp.

Holdgate, M.W. 1964: Terrestrial ecology in the Maritime Antarctic. In Carrick, R., Holdgate, M.W. \& Prévost, J. (eds): Biologie Antarctique. Herman Press, Paris: $181-194$.

Huntley, B.J. 1970: Altitudinal distriburion and phenology of Marion Island vascular plants. Tydskrif vir Natuurwetenskappe 10: 255-262.

Jenkin, J.F. 1972: Studies on plant growth in a subantarctic environment. Unpublished PhD thesis. University of Melbounc.

Jenkin, J.F. 1975: Macquarie Island, Subantarctic. In Rosswall, T. \& Heal, O.W. (eds): Structure and Function of Tundra Ecosystems. Eonlogtal Bulletins (Soucholm) 20 : $375-397$

Jenkin, J.F. 8x Ashton, D.H. 1970; Productivity studies on Macquarie lstand vegetation. In Holdgate, M.W. (ed): Antantic Ecology Vol. 2. Academic Press, Londor: $851-863$

Klok, C.J. \& Chown, S.L. 1997: Critical thermal limits, temperature tolerance and water balance of a sub-Antarctic caterpillar, Pringleophaga marioni (Lepidoptera: Tineidae). Journal of Insect Physiology 43: 685-694.

Lawson, G.J. 1985: Decomposition and nutrient cycling in Rostkovia magellanica from two contrasting bogs on South Georgia. In Siegfried, W.R., Condy, P.R. \& Laws, R.M. (eds): Antarctic Nutrient Cycles and Food Webs. Springer, Heidelberg: 186-191.

Lawson, G.J. 1988: Using the cotton strip assay to assess organic matter decomposition patterns in the mires of South Georgia. In Harrison, A.F., Latter, P.M. \& Walton, D.W.H. (eds): Cotton Strip Assay: an Index of Decomposition in Soils. ITE Symposium 24, Institute of Terrestrial Ecology, Grange-over-Sands: 134-139.

Lewis Smith, R.I. 1984. Terrestrial plant biology of the subAntarctic and Antarctic. In Laws, R.M. (ed.): Antarctic Ecology. Vol. I. Academic Press, London: 61-162.

Lewis Smith, R.I. \& Walton, D.W.H. 1975: South Georgia, Subantarcuc In Rosswall, T. \& Heal, O.W. (eds): Stucure and Function of Tundra Ecosystems. Ecological Bulletins (stockholm) 20: 399-423 
Lindeboom, H.J. 1984: The nitrogen pathway in a penguin rookery. Ecology 65: 269-277.

Miller, B.C., Webber, P.I., Oedhel, W.C. \& Tieszen, L.L. 1980: Biophysical processes and primary production. In Brown. 1. Miler, PC., Tieszen, L.L. \& Bunnell, F.L. (eds): An Arctic Ecosystem. The Coastal Tundn at Barrow, Alaska. USARP Synthesis Serios 12:60-101.

Muc, M. 1977: Ecology and primary production of sedge-moss meadow communtics, Truelove Lowand. In Bliss. I.C.,

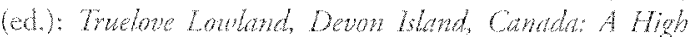
Artic Ecosystem. University of Alberta Press, Edmonton: $157-184$

Ostby, E., Perg, A., Blehr, O., Espeland, M., Gatare, E., Hagen, A., Hesjedal, D. Magrar, S., Kielvik, S., Licn, L., Mysterud, I., Sandhaug, A., Skar, H. I., Shatrtweit, A., Skre, O., Slogyland, T., Solhoy, T., Stenseth, N.C. 8. Wielgolashi, F. 1975: Hardangervidda, Norway, $/ n$ Rosswall, T. \& Hcal, O,W. (eds): Sructure and Function of Tundra Ecosystems. Ecologiat Bulletin (Stockholm) 20. $225-264$

Pakarinen, P. Vite, D.H. 1973: Primary production of plant communities of the Trudove Lowland, Devon Island, Canada - moss communites. In Blice, $\mathrm{I}$.... Whelgolaski, FE. (eds): Primaty Production and Production Processes, Thlon Bione. Tundra Biome Steering Commites. Stockholm: 37-46.

Pammenter, N.W., Drennan, P.M. \& Smith, V.R. 1986: Physiological and anatomical aspects of photosynthesis of two Agrostis species at a sub-Antarctic Island. New Phytologist 102: 143-160.

Porsild, A.E. 1964: Illustrated flora of the Canadian Arctic Archipelago, 2nd edition. National Museum of Canada Bulletin 146: 218 pp.

Pratt, R.M. \& Lewis Smith, R.I. 1982: Seasonal trends in chemical composition of reindeer forage plants on South Georgia. Polar Biology 1: 13-31.

Pagh, I.S.A. 2004: Biogeography of spiders (Ataneae: Arachnida) on the islands of the Southen Ocean. Journd of Natumat Histom 38: 1461-1487.

Reader, R.J. 1978: Primary production in nothem bog marshes in Good, R.E., Whighan, D.F \& Simpson R.L. (eds) Freshuater Wetlands. Ecological Processes and Monagement Potenial. Academic Press, New York: 53-62

Rosswall, T., Hower-Ellh, J.G. K., Johnansson, L.G., Jonnsson, S., Ryden, B.E. \& Sonnesson, M. 1975: Stordalen (Abisto) Sweden. In Rosswall, T. \& Heal, O.W. (eds): Structure and function of tundra ecosystems. Ecologich Balletizu. (Stukholm) 20: 265-294.

Rosswall, T. \& Heal, O.W. 1975: Structure and function of tundra ecosystems. Ecological Bulletins 20: 1-450.

Rouault, M., Mélice, J-L., Reason, C.J.C. \& Lutjeharms, R.E. 2005: Climate variability at Marion Island, Southern Ocean, since 1960. Journal of Geophysical Research 110 C05007, doi: 10.1029/2004JC002492.

Rutherford, M.C., Mucina, L. \& Powrie, L.W. 2006: Biomes and bioregions of Southern Africa. In Mucina, L. \& Rutherford, M.C. (eds): The Vegetation of South Africa, Lesotho and Swaziland. Strelitzia 19: 30-51. South African National Biodiversity Institute, Pretoria.

Ryan, P.G. \& Bester, M.N. 2007: Pelagic predators. In Chown, S.L. \& Froneman, P.W. (eds): The Prince Edward Islands. Land-Sea Interactions in a Changing Ecosystem. African Sun Media, Stellenbosch, in press.

Sachs, J.P. \& Anderson, R.F. 2005: Increased productivity in the subantarctic ocean during Heinrich events. Nature 434: $1118-1121$

Selmi, S. \& Boulinear, T. 2001: Ecological biogeography of Southern Ocean islands: the importance of considering spatial issues. American Naturalist 158: 426-437.

Sintons, PL. \& Sixght, J.S. 1978: The structure and funcrion of ten western North Anerican grasslands. III. Net primary production turnover and efficiencies of energy capture and water use. Joumal of Eology 66: 573-597.

Slabber, S. \& Chown, S.L. 2002: The first record of a terrestrial crustacean, Porcellio scaber (Isopoda, Porcellionidae), from sub-Antarctic Marion Island. Polar Biology 25: $855-858$

Smith, V.R. 1976a: The effect of burrowing species of Procellariidae on the nutrient status of inland tussock grasslands on Marion Island. South African Journal of Botany 42: 265-272.

Smith, V.R. 1976b: Standing crop and nutrient status of Marion Island (sub-Antarctic) vegetation. South African Journal of Botany 42: 231-263.

Smith, V.R. 1977: Vegetation standing crop of the grey lava flows and of the eastern coastal plain on Marion Island. South African Joumal of Botany 43: 105-1 I4

Smith, V.R. 1978: Animal-plant-soil nutrient relationships on Marion Island (sub-Antarctic). Oecologia 32: 239-253.

Smith, V.R. 1987a: Production and nutrient dynamics of plant communities on a sub-Antarctic Island. 1. Standing crop and primary production of mire-grasslands. Polar Biology 7: 57-75.

Smith, V.R. 1987b: Production and nutrient dynamics of plant communities on a sub-Antarctic Island. 3. Standing stocks, uptake and loss of nutrients in mire-grasslands. Polar Biology 8: 135-153

Smith, V.R. 1988: Production and nutrient dynamics of plant communities on a sub-Antarctic Island. 5. Nutrient budgets and turnover times for mire-grasslands, fjaeldmark and fernbrakes. Polar Biology 8: 255-269.

Smith, V.R. 199 I: Atmospheric carbon dioxide levels at Marion Island. South African Journal of Science 87: 535-536.

Smith, V.R. 1992: Terrestrial slug recorded from sub-Antarctic Marion Island. Journal of Molluscan Studies 58: 80-81.

Smith V.R. 2002: Climate change in the sub-Antarctic: An illustration from Marion Island. Climatic Change 52: 345-357.

Smith, V.R. 2003: Soil respiration and its determinants on a subAntarctic island. Soil Biology \& Biochemistry 35: 77-91

Smith, V.R. 2005: Moisture, carbon and inorganic nutrient controls of soil respiration at a sub-Antarctic island. Soil Biology if Biochemistry 37: 81-91

Smith, V.R. 2007a: Terrestrial and freshwater primary production and nutrient cycling. In Chown, S.L. \& Froneman, P.W. (eds): The Prince Edward Islands: Land-Sea Interactions in a Changing Ecosystem. African Sun Media, Stellenbosch, in press.

Smith, V.R. 2007b: Introduced slugs and indigenous caterpillars as facilitators of carbon and nutrient mineralisation on a sub-Antarctic island. Soil Biology er Biochemistry 39: $709-713$

Smith, V.R., Avenant, N.L. \& Chown, S.L. 2002: The diet and impact of house mice on a sub-Antarctic island. Polar Biology 25: 703-715.

Smith, V.R. \& Froneman, P.W. 2007: Nutrient dynamics in the vicinity of the Prince Edward Islands. In Chown, S.L. \& Froneman, P.W. (eds): The Prince Edward Islands: Land-Sea Interactions in a Changing Ecosystem. African Sun Media, Stellenbosch, in press.

Smith V.R. \& Gremmen N.J.M. 2001: Turgidosculum complicatulum on sub-Antarctic Marion Island: carbon acquisition response to climate change. Polar Biology 24: 455-459.

Smith, V.R. \& Mucina, L. 2006: Vegetation of Subantarctic Marion and Prince Edward Islands. In Mucina, L. \& Rutherford, M.C. (eds): The Vegetation of South Africa, Lesotho and Swaziland. Strelitzia 19: 698-723. South African National Biodiversity Institute, Pretoria.

Smith, V.R. \& Steenkamp M. 1990: Climatic change and its ecological implications at a sub-Antarctic Island. Oecologia 85: $14-24$ 
Smith, V.R. \& Steenkamp, M. 1992a: Soil nitrogen transformations on a sub-Antarctic island. Antarctic Science 4: 41-50.

Smith, V.R. \& Steenkamp, M. 1992b: Macroinvertebrates and litter nutrient release on a sub-Antarctic island. South African Journal of Botany 58: 105-116.

Smith, V.R. \& Steenkamp, M. 1992c: Soil macrofauna and nitrogen on a sub-Antarctic island. Oecologia 92: 201-206.

Smith, V.R. \& Steenkamp, M. 1993: Mactoinvertebrates and peat nutrient mineralization on a sub-Antatctic island. South African Journal of Botany 59: 106-108.

Smith, V.R., Steenkamp, M. \& French, D.D. 1993: Soil decomposition potential in relation to environmental factors on Marion Island (sub-Antarctic). Soil Biology and Biochemistry 25: 1619-1633.

Smith, V.R. \& Steyn, M.G. 1982: Soil microbial counts in relation to site characteristics at a sub-Antarctic Island. Microbial Ecology 8: 253-266.

Swift, M.J., Heal, O.W. \& Anderson, J.M. 1979: Decomposition in Terrestrial Ecosystems. Studies in Ecology 5. Blackwell Scientific Publications, Oxford: 372 pp.

Van Aarde, R.J. \& Jackson, T.P. 2007: Food, reproduction and survival in mice on sub-Antarctic Marion Island. Polar Biology 30: 503-511.

Van Cleve, K. \& Alexander, V. 1981: Nitrogen cycling in tundra and boreal ecosystems. In Clark, F.E \& Rosswall, T. (eds): Terrestrial Nitrogen Cycles. Processes, Ecosystem Strategies and Management Impacts. Ecological Bulletins 33: 375-404.

Van der Merwe, M., Chown, S.L. \& Smith V.R. 1997: Thermal tolerance limits for six weevil species (Coleoptera, Curculionidae) from sub-Antarctic Marion Island. Polar Biology 18: 331-336.

Wace, N.M. 1965: Vascular plants. In Van Miegham, J. \& Van Oye, P. (eds): Biogeography and Ecology in Antarctica. Dr. W. Junk, The Hague: 201-266.

Walton, D.W.H. 1985: Cellulose decomposition and its relationship to nutrient cycling at South Georgia. In Siegfried, W.R., Condy, P.R. \& Laws, R.M. (eds): Antarctic Nutrient Cycles and Food Webs. Springer, Heidelberg: 192-199.
Walton, D.W.H. \& Lewis Smith, R.I. 1980: Chemical composition of South Georgian vegetation. British Antarctic Survey Bulletin 49: 117-135.

Webber, I.J. 1978: Spatial and temporal variation of the vegetation and its production. In Theszen, L.L. (ed.): Vegetation and Producuon Ecology of an Alaskan Arctic Tundra. Ecologicat Studies 29:37-112.

Whighan, D.F., McCormick, I., Good, R.E. \& Simpson R.L. 1978: Biomass and primary production in freshwater tidal wetands of the Middle Adantic coast. Th Good, R.E., Whigham, D.F \& Smpson, R.L. (cds): Feshuater Wethands. Ecologiad Processes and Managentent Potentad. Academic Press, New York: 3-20.

Whinam, J., Chilcott, N., \& Bergstrom, D.M. 2005: Subantarctic hitchhikers: expeditioners as vectors for the introduction of alien organisms. Biological Conservation 121: 207-219.

Wielgolaski, F.E., BHiss, L.C., Svoboda, J. E. Doyle, G. 1981: Primary production of tundra. In Bliss, 1.C. Heal, O.W. \& Moore, 1.J. (eds): Tandw Ecosyteris: A Compantive Anabsis. Cambridge Universiry Rress, Cambridge: $187-225$.

Wielgolaski, FE. \& Kiflvik, \$. 1973: Production of plant (vascular plants and cryprogans) in alpine turdra, Hardangervidda. In Bliss, L.C., Whelgolaski, E.E. (eds): Irimary Production and Production Processes, Tundna Biome. Tundra Bione Steerng Committee, Stockholm: 75-86.

Wynn-Williams, D.D. 1988: Cotton strip decomposition in relation to environmental factors in the Maritime Antarctic. In Harrison, A.F., Latter, P.M. \& Walton, D.W.H. (eds): Cotton Strip Assay: an Index of Decomposition in Soils. ITE Symposium 24, Institute of Terrestrial Ecology, Grangeover-Sands: $126-133$.

Yoshikawa-Inoue, H. \& Ishii, M. 2005: Variations and trends of $\mathrm{CO}_{2}$ in the surface seawater in the Southern Ocean south of Australia between 1969 and 2002. Tellus Series $B$ - Chemical and Physical Meteorology 57: 58-69.

(accepted 28 May 2007) 